\title{
ÇAĞIN SORUNLARI BAĞLAMINDA BATI VE İSLAM EĞİTIM ANLAYIŞININ KARŞILAŞTIRILMASI
}

\begin{abstract}
Mahmut Dündar*
$\ddot{\mathbf{O} z}$

Tüm eğitim sistemlerinde eğitim ve öğretim faaliyetlerinin amacı, insanın huzur ve mutluluğunu temin etmektir. Bu da insanın fitratında bulunan-gerek duyulan maddi ve manevi ihtiyaçlarının karşılanması ve yaşadığı problemlerin giderilmesi ile mümkün olabilmektedir. Batı eğitim sistemleri, insanın manevi ihtiyaç ve sıkıntılarını göz ardı ederek, materyalist bir anlayışla maddi çıkar ve arzuları hedef edinmektedir. Böylece burada bir taraftan insanın manevi ihtiyaçlarının giderilmesi eksik kalırken, öbür taraftan modern çağda olup da ulaşılamayan ve hayal edilip de gerçekleştirilemeyen ideallere dayalı oluşan psikolojik sorunlar da çözümsüz kalabilmektedir. Oysaki İslami eğitim, fitrata uygun olarak insanın maddi ve manevi ihtiyaçlarının teminini birlikte ele almaktadır. Aynı zamanda yaşanan çağın psikolojik sorunlarına karşı da Allah'a iman ve tevekkül anlayışını benimseterek çözüm oluşturulabilmektedir. Binaenaleyh İslami eğitim sisteminde, insanın dünya ve ahiret mutluluğu ile huzuru sağlanabilmektedir. Bu makalede Batı eğitim sisteminin temel anlayışı ve bu anlayışın yaşanan çağdaş sorunlara karşı çözümsüzlüğü üzerinde durulurken, İslami eğitim sisteminin temel anlayışı ve bu anlayışın yaşanan çağdaş sorunlara getirdiği çözümler üzerinde durulmaktadir.
\end{abstract}

Anahtar Kelimeler: Batı Eğitim Sistemi, İslami Eğitim, Çağdaş Sorunlar ve Çözümü.

\section{COMPARISON OF WESTERN AND ISLAMIC EDUCATION APPROACH IN THE CONTEXT OF CONTEMPORARY ISSUES}

\begin{abstract}
In all education systems the aim of education and teaching activities is to provide happiness and peace to people. That can be just because of being suplied financial and moral needs which come from creation of human and being solved the problems that people live. Western education system ignores person's moral needs and problems, and it aims material gains and desires with a materialist perception. So that on the one hand suplying of the moral needs of person remains incomplete, on the other hand psychological problems that ocur because of ideals that being dreamed but not being made real and although existing not being reached. Whereas Islamic education deals with suplying of both material and moral needs of people. Also it builds solutions to psychological problems of the age by adopt people the resignation understanding and
\end{abstract}

Makale Gönderim Tarihi: 30.01.2019, Kabul Tarihi: 26.04.2019

Doi: $10.26791 /$ sarkiat.519857

* Dr. Öğr. Ü., Yüzüncü Yıl Üniversitesi, İlahiyat Fakültesi, Din Eğitimi Anabilim Dalı, mahmutlardan@hotmail.com

ORCID ID: orcid.org/0000-0003-1856-6494 
believing Allah.In Islamic education system person's happiness of world and eternity and person's peace are provided. In this article the basic perception of western education system and the deadlock of this perception to the age problems, and also the basic perception of Islamic education system and the solution that this perception brings to the age problems are dealt with.

Keywords: Western education system, Islamic education, contemporary issues and solution.

\section{GIRIŞ}

Sosyal bir varlık olan insan, bireysel ve toplumsal olarak mutlu ve huzurlu bir yaşamı elde etme amacindadır (Bayraktar, 1994: 15-18). Bu da kolay olmamaktadır. Zira her insan; bireysel farklılıklar, çevresel etkenler, maddi ve manevi imkânlar, düşünce ve inanç yapısı gibi etkenlere bağlı aldığı eğitim ile huzurlu ve mutlu olmada değişiklik göstermektedir. Böylece insanoğlu, hazır olmayan ham kabiliyetlerle dünyaya geldiğinden biyolojik, psikolojik ve sosyal yapısı gereği hayatın her aşamasında özelliklerine uygun eğitilmeye ihtiyaç duymaktadır (Mengüşoğlu, 1971: 42).

Günümüz modern çağın insanları, bilim ve teknolojinin gelişmesine dayalı iletişimin ve etkileşimin tesiri ile kendilerini yenileme ve değiştirme ihtiyacı duymalarının yanında çağın birçok sorunlarını yaşamaktadırlar ya da bu sorunlardan bir şekilde haberdar olmaktadırlar. Haliyle büyük beklentilerin içerisine girilmesi ve bu beklentilerin karşılanamaması ya da yaşanan zulüm ve sıkıntılar karşısında kayıtsız kalınması, bireyi rahatsız ve huzursuz etmektedir. Dolayısıyla çağın değişmesine bağlı olarak ihtiyaç duyulan eğitim alanları da değişmekte ve artmaktadır (Bayraklı, 2015: 17).

Genel anlamda eğitimin temel hedefi, sosyal bir varlık olan insanı kademe kademe kemale erdirerek huzur ve mutluluğunu temin etmektir (Keklik, 1967: 165). Bu da eğitim ile bireyde oluşturulabilen istendik yönde kalıcı davranış değişikliği (Dündar, 2011: 19) ile olabilmektedir. Eğitimden beklenen olumlu ve huzurlu bir yapıya kavuşma, Batı eğitim sistemleriyle gerçekleşememektedir. Burada insanın manevi boyutu göz ardı edilmekte ve işe sadece materyalist bir anlayışla bakılmaktadır. Batı, maddiyata ulaşmayı da rasyonalizm ve amprizm ile gerçekleştirmektedir. $\mathrm{Bu}$ anlamda 15. ve 16. yüzyıllardan itibaren başlayan rönesans hareketiyle Fransız eğitimi, gerçeğe akılla ulaşma olan rasyonalizme dayanırken İngiliz eğitimi ise, gerçeğe tecrübelerle ulaşma olan amprizme dayanmaktadır (Cramer \& Browne 1974 : 82-86; Hesapçıŏlu, 2009: 125-126).

Modernleşme ile birlikte sermayenin Batı'da el değiştirmesi neticesinde kapitalizm etkili olduğu gibi, kültürde de değişmeler meydana gelmiştir. Bireyin düşünce, inanç ve üretim çabaları gelenekten ve otoriteden bağımsız olarak ele alınmış, insan ve dünya akıl merkezli bir anlayışla yeniden tanımlanmıştır. Tanrı odaklı bir yaşam ve insan anlayışı yerine, akıl merkezli bir yaşam ve insan anlayışına geçilmiştir (İnalcık, 2006: 289-293)

İslami eğitim sisteminin temel hedefi ise, insanın maddi ve manevi huzurunu sağlamak olduğundan burada bireyin bulunduğu dönemde yaşadığı ve beklediği sorunlara çözüm getirilebilmektedir. Fıtratının gerektirdiği maddi ihtiyaç karşılandığı gibi, manevi ihtiyaç da karşılanmaktadır. Dolayısıyla birey, Yüce Allah'a olan tam teslimiyeti ve yaratılıştan gelen fitratın ihtiyaç ve gereklerine göre davranmayı öğrenerek mutlu ve huzurlu bir yaşamı edinebilmektedir. Böylece Yüce Allah'ın terbiye etmek, büyütmek, yetiştirmek anlamlarına gelen, merhamet, şefkat, yakın ilgi ve doğru yola iletme 
anlamlarını da içeren "Rab" sıfatının gereği olarak terbiye edilen ve eğitilen $\mathrm{Hz}$. Peygamber, aldığı eğitimle ümmetini eğitmiştir. Demek ki Yüce Allah, doğrudan Hz. Peygamber'i ve dolaylı olarak ümmetini eğittiğinden İslami eğitim, "Kur'an-1 Kerim" ve "Hz. Muhammed'in Sünneti" diye iki temel kaynağa dayanmaktadır. Böylece İslami eğitimde, Hz. Peygamber'in sözleri ile insanlara ulaştırılan ilahi buyruklar çerçevesinde "oku!" emri doğrultusunda, okumaya-bilgiye önem verilmiş ve burada hiçbir sınıfsal ayrıma yer verilmemiştir (Başar, 2010: 30-32).

Aşağıda ele alınacağı üzere ilgili birçok kaynaktan yararlanarak modern çağın gerektirdiği ve ürettiği sorunların karşısında Batı ve beşeri eğitim sistemlerinin çözümsüzlüğü ortaya çıkarılmaktadır. Ayrıca İslami eğitimin temel kaynaklarından da yararlanılarak, bu eğitim sisteminin önemsediği değer ölçütler ele alınarak bireyin yaşadığı maddi ve manevi sorunların çözümü irdelenmektedir.

\section{1. Çağdaş Sorunlar Karşısında Batı Eğitim Anlayışı}

Batı eğitim sisteminin kaynağında, İslami eğitim sisteminin kaynağında bulunan ve İlahi kaynak olarak nitelendirilen Kur'an ve Sünnetin yerine, insanın düşünce ürünü olan felsefe ve materyalist anlayış bulunmaktadır (Bayrakl1, 1995: 519). Haliyle modern Batı eğitim sistemlerinin çoğunda dünyevi amaçla kendilerinden en üst düzeyde faydalanılmak üzere bireyler, kabiliyetleri doğrultusunda eğitilmektedir. Dolayısıyla İslami eğitimde esas alınan empati kurmak ve başkasını düşünerek ona yardımcı olmak ile Allah'a kul olma bilincini kazandırmak olan "iyi insan" veya "kamil insan" yerine, daha çok para kazanmak ve toplumda söz sahibi olmak gibi hedefleri içeren "iyi vatandaş" yetiştirmek esas alınmaktadır (Halstead, 2004: 523). Böylece oldukça servet edinip ekonomik refaha ulaşmak, Batı toplumlarının çoğunluğunun en son hedefi olmaktadır. Birçok yönde fert ve toplum münasebetlerine hâkim olan bu anlayış biçimiyle gerçek huzura ermek mümkün olmamaktadır. Zira manevi boyutu eksik kalan insan, bu eksikliğini gidermek ve doyurmak amaciyla yüce bir varlığı aramaya başlayacaktır. Gerçek şudur ki; teknolojik gelişmelere bağlı çağdaş medeniyetin getirdiği kolaylıklar inkâr edilemz. Ancak bireyin manevi ihtiyaçlarının olduğu göz ardı edilemeyeceği de unutulmamalıdır. Dolayısıyla Batı eğitim sistemi, insanın manevi mutluluğunun salt maddi refaha dönüştürülmesine, dinin getirdiği mesajın unutulmasına ve birtakım fitri ihtiyaçların göz ardı edilmesine sebep olmaktadır. Birçok çağdaş fikirlerin çatışma alanı durumunda bulunan yeni neslin düşünceleri, gün geçtikçe bu ortamdan fazlasiyla olumsuz etkilenmektedir (Musevi Lari, 2001: 11-16).

Batı eğitim sistemine bağlı Batı medeniyetinin getirdiği ve sosyal yaşamı kolaylaştırıcı bolca üretim, teknolojik araç, kaynak ve servet görmezden gelinememektedir. Zira bilimsel ve teknik açıdan oldukça ilginç ve süratlı ilerlemeler görüldügünden çağımız bilim ve teknolojinin zafer ve başarı çağı olarak adlandırılmaktadır. Bütün bu gelişmeler karşısında ne yazık ki Batı'nın eğitim sistemine dayalı medeniyeti, önemli ölçüde eksiklik, olumsuzluk ve zaaflarla doludur. Çünkü Batı medeniyeti, insanlığın saadetini sağlayan fazilet ve erdemleri hızla yok etmiş ve nihayetinde muasır toplumu önemli çöküşlere maruz bırakmıştır. Görüldüğü üzere Batı teknolojisi doruk noktasındadır, insanlar her an yeni şeyler keşfetmektedir, hızla topluma yayılan teknolojik gelişmenin sonuçları, insanların ruhsal durumlarını olumsuz etkilemektedir. Dolayısıyla bilim ilerledikçe ahlak ve fikir gerilemiş, ihtilaf ve tartışma unsurları hız kazanmıştır. Zira Batı toplumu ruhi ve insani değerleri bir kenara itmiş ve adeta kendi ürettikleri makineye köle olmuştur. $\mathrm{Bu}$ da, mutluluğu tatmaktan ve huzura kavuşmaktan uzak olması anlamına gelmektedir. Nitekim bilim ve teknoloji, hayata refah sağlayıcı belli bir düzen vermekte, ama saadet ve huzur getirememektedir. Bilim ve teknoloji ile saadet ve huzur farklı şeylerdir. Bilim ve teknoloji faydalıyı veya zararlıyı, iyiyi, kötüyü, güzeli 
ve çirkini ayırmamakta, ancak bunları tanımaya ve doğruyu yanlıştan ayırmaya yardımcı olmaktadır. Bundan dolayıdır ki, salt bilim üzerine kurulu bir hayat cehenneme sebep olabildiğinden İngiliz filozof Bertrand Russell'e (1872-1970) göre böyle bir hayatı sağlayan düzene karşı mücadele edilmelidir (Russeell, 1972: 51-62).

Batı medeniyeti insanlık için çok değerli gelişmelere sahne olmuş ise de, binlerce korkunç ahlaksızlık ve cinayetlerle iç içe bir sorumsuzluğu da beraberinde getirmiştir. Buna dayalı hevâ ve hevesler, insanın düşünce ve psikolojisini bozduğu gibi, hayatını da tehlikeye düşürmüştür. Acı bir gerçektir ki, bu bilimsel süreç, insanın manevi hayatına olumlu katkı sağlamazken sosyal hayatına ciddi olumsuzluklar eklemektedir. Böyle bir dünyada insan akıl, çıkar ve menfaatin buyruğunda olduğundan ekonomik bağl1lıktan başka bağl1lı̆̆ anlayamamaktadır (Musevi Lari, 2001: 25-29).

Russell, başta İngiltere olmak üzere, Batılı devletlerin sömürgecilik anlayışıyla hareket ettikleri, dolayısıyla yaptıkları ve organize ettikeri savaşlarla kan ve gözyaşı döktüklerini, özgürlük ve kişisel haklardan söz etmelerinin sadece teoride kaldığını, pratikte ise tersi bir uygulamada olduklarını dile getirmiştir (Louise Crips, 1997: 19).

Haliyle Batı eğitim sistemi, oluşturduğu medeniyet sayesinde toplumu huzura kavuşturamadığı gibi, yaşadığı çağda yeni yeni sorunların oluşmasına da sebep olmaktadır. Böylece Batı, Freud'un sözlerine kanarak toplumun şehvetini serbestçe tatmin edebileceği bir ortamı oluşturması, başta Batı'nın kendisi olmak üzere onu taklit eden toplumların intihar, suç işleme, fuhuş, sinirsel baskı ve psikolojik hastalıklar, delirme ve sık sık kriz geçirme gibi birçok olumsuzlukların yaşanmasına sebep olmuştur. Nitekim İsveç'te tam 20 yıl süreyle tanınan sınırsız bir cinsel serbesti sayesinde ülkenin gençleri korkunç durumlara düşmüştür. $\mathrm{Bu}$ duruma karşı dehşete kapılan bilim insanları ve sorumlular, ne yapacaklarını bilemez duruma gelmişlerdir. Dolayısıyla vuku bulan korkunç tablo tehlikeli boyutlara varacak kadar toplumsal bozulmalara sebep olduğundan, bu ülkenin parlamentosu bu konuyu ana gündemine almış ve İsveç başbakanı açık bir şekilde; "Yirmi yıl süregelen bu hatamızı telafi edebilmek için kırk yıllık çalışma yapmamız gerekiyor." diye acı bir gerçeği itiraf etmiştir. Alman devletinin verdiği istatistiklere gore, Batı ve Doğu Almanya'da meşru sayılan evlilik dışı ilişkilerin dışında tecavüz ile dünyaya gelen gayri meşru çocuk sayısı yüz binleri bulmakta ve bakımları devletçe üstlenilmektedir. Amerika'da bilimsel bir kuruluşun yaptığı araştırmaya gore, çeşitli sınıf ve yaş gruplarında bulunan eşlerin birbirlerine karşı ihanetlerine bakıldığında; kocaların \%50'si eşlerine ihanet etmekte, ihanet etmeyenlerin çoğu ise, ya skandal olur korkusuyla, ya da firsatını yakalayamadıklarından eşlerine sadık kalmaktadır. Newyork'ta yapılan telefon görüşmelerinin incelenmesi sonucunda birçok kadının da kocasına ihanet ettikleri anlaşılmıştır. Yine yapılan bir araştırmada Amerika'da yılda yüz binlerce gayri meşru bebeğin meydana geldiği ve yıllık yapılan kürtajın bilançosunun milyonları bulduğu ve bunun \%50'sinin evli olmayan kızlara ait olduğu ortaya konulmuştur. Yine Londra'da her yıl 50 bini aşkın düşük ve kürtaj yapıldığı ve doğan her 20 çocuktan birinin gayri meşru olduğu belirtilmektedir (Musevi Lari, 2001: 75-83).

Çağdaş medeniyetin ön sıralarında yer alan Fransa halkından her yıl yaklaşık 35 bin kişinin intihara teşebbüs ettikleri tespit edilirken ta 1976'da Alman polisi, o y1l içerisinde intihara kalkışıp kurtarılan erkeklerin sayısının 6 bin, kadın sayısının ise 7 bin olduğunu tespit etmiştir. Newyork polisi, sadece Newyork'ta 100 bini aşkın eroinman olduğunu ve 80 kişiden birinin morfin kullandığını, bunun da zengin kesim ile sanatçılarda daha yaygın odluğunu belirtmiştir. Amerika Devlet Başkanı Kenedy, 1962'de yaptığı bir konuşmada; "Amerikan gençliğinin sorumsuz, zevk ve eğlenceye düşkün, asker olan her yedi gençten altısının yetersiz ve şehvet perest olmakla fiziki ve 
manevi yeteneklerini kaybettiklerinden Amerika’yı çok acı bir geleceğin beklediğini” itiraf etmiştir. Aynı yıl Sovyet Lideri Kruşçev de; "Sovyetlerin geleceği tehlikede, çünkü gençlerin durumu ümit verici değil, sorumsuz ve şehvetperest bir gençliğimiz var." itirafinda bulunmuştur (Musevi Lari, 2001: 85-87).

Batıda kilise, her ne kadar güçlü propaganda ve nüfuzu sayesinde Batı toplumunun kültürel ve sosyal yönlerine müdahale ediyor ise de, bu etkinliği ile halkın ahlak ve maneviyatını kurtarıp iman ve takvaya vesile olamamıştır. Zira mensuplarını günah ve ahlaksızlıkta önemli ölçüde serbest bırakmış olan bir din, onları ahlaki çöküş ve bozulmalardan kurtaramamaktadır. Çünkü Hıristiyanlık, yapılan tahrifatlarla sadece akidevi meselelerdeki hurafe ve batıl inançlara maruz kalmamış, aynı zamanda Allah'a ibadette de yozlaşmalar yaşanarak kendi hakikatlerini yetirir hale gelmiştir. Nitekim kilise, şehvetperest gençleri kendisine çekebilmek için müzikli dans salonlarına sahip olmuştur. İbadethanelerde yapılan bu faaliyetler, din ve dini değerleri açıkça alaya almak anlamına gelmektedir. Böylece Batı; dini, bireyin salt özel hayatı ve iç dünyasıyla ilgili bir olay olarak görüp günlük yaşamın gerçeklerinden tamamen uzaklaştırdığından, yani din ile dünyayı ayrı şeylermiş gibi telakki ettiğinden büyük bir hataya düşmüştür. Haliyle birey, inancı gereği yapması gereken bir davranışı; pratik yaşamında "yapmaması gereken bir davranış" olarak görebilmekte ve kendi kendisiyle çelişebilmektedir. Dolayısıyla günlük yaşamda ciddi sapma ve çıkmazlar oluşmuş ve her türlü hak ve hakikat; kolayca şehvet ve nefsi arzulara feda edilmiş, sonuçta fesat ve bozulmanın toplumumun geneline yayılmasına sebep olmuştur (Musevi Lari, 2001: 8994).

Muhammed Esed de 1922'de Avrupa'dan ayrilıp Müslüman olduktan sonra İslamiyet'teki ilkeleri gördüğünden Batı'yı, özellikle İngiltere'yi ve politik hedeflerini eleştirdiği gibi; Hıristiyan dünyasının din, toplum, kültür, medeniyet, aile, ekonomi vs. anlayışlarını da çok sert bir dille eleştirmiştir. Böylece materyalist kabiliyet ve anlayışa sahip olan Batı'nın, belli başlı anlayışlarında manevi boşluğu dolduran dine karşı olduğunu ve eğitim sistemini de buna göre şekillendirdiğini belirtmiştir (Muhammed Esed, 2017: 19, 77).

\section{2. Çağdaş Sorunlar Karşısında İslam Eğitim Anlayışı}

Yukarıda belirtildiği üzere Batı eğitiminde esas olan "iyi vatandaş" yetiştirmek iken İslami eğitimde esas olan "iyi insan" veya "kamil insan" yetiştirmektir. Bu da seküler eğitim anlayışının tersine maddi ve manevi birçok hedefi kapsamaktadır ki bununla insanın Allah'la ilişkileri başta olmak üzere, kendisiyle, toplumla ve çevresiyle olumlu ilişkiler geliştirilebilmektedir (Köylü, 2017: 54-55). Zira İslamî eğitimde hedeflenen "iyi insan"ın yetiştirilmesi, Batı eğitiminde hedeflenen "iyi vatandaş"ın yetişmesi anlamına da gelmektedir. Ancak tersinin söylenmesi mümkün görünmemektedir. (Attas, 1979: 32).

İslam'ın bilgi geleneğinde edinilen bilgilerle fen ve tekniğe sahip olmanın yanında bilgeliğe ulaşarak hikmet sahibi ve arif olmak vardır. Böylece ilim ile uğraşmak aynı zamanda Allah'a yaklaştıran teabbudi bir hareket olduğundan burada dünya ve ahiret saadeti birlikte hedef edinilmektedir. Dolayısıyla İslam epistemolojisinde bulunan ahiret anlayışı, belirtilen hedefi temin edebilirken; Batı epistemolojisinin ahiret anlayışından yoksun oluşu, bu hedefi gerçekleştirememektedir (İmamoğlu, 2013: 185).

İslami eğitime göre öğrenciler öyle eğitilmelidirler ki İslam'ın derinden hissedilen etik değerleriyle bilgiyi görüp edinebilsinler. Binaenaleyh onlar, yalnız bilgi edinme meraklarını yahut da sadece dünyevi menfaatlerini temin etmek üzere eğitilmezler, belki akıllı ve kamil kimseler olarak yetişerek kendilerine, ailelerine, milletlerine ve tüm 
insanlığa ahlaki ve fiziksel refahı geliştirmek için eğitilirler. Bu da Allah'a olan içten ve samimi inanca dayalı Allah'ın belirlediği tüm hükümleri kalben kabulüne dayanmaktadır (Husain \& Ashraf, 1979: 1). Bu amaç ise, vahyedilen din tarafından ortaya konulduğundan bir nevi objektif olup bireysel düşünce ve tecrübeye göre çeşitlilik göstermemektedir. Müslüman'ın bakış açısına göre bilginin uygun kullanımı, insanların Allah hakkında bilgi edinmelerine, İslami kurallara göre yaşamalarına ve yaratılış amaçlarını gerçekleştirmelerine vesile olmaktır ( Halstead, 2012: 277-279). Zira bilginin doğası, onu koruyan veya ortaya çıkaran zihnin ya da ruhun manevi, ahlaki ve zihinsel niteliklere bağlı oluşudur. Oysaki Batı eğitimi, ilmi ve seküler değerlerle iç içe olup seküler ilişskilere dayalıdır (Wan Daud,1998:309). Böylece İslami gelenekte aydınlar, vahye saygı duyarlarken Batı geleneğinde ise vahy utanç kaynağı olarak görülmektedir (Halstead, 2012:287).

Batı toplumlarında olduğu gibi, Müslüman toplumda da çağın getirdiği sorunlar yaşanmaktadır. Hemen hemen hiçbir toplum kapalı kalmayarak her toplum diğer toplumlarda meydana gelen gelişmelerden haberdar olarak, onlardan gelecek etkilere açık toplum haline gelmektedir. Zira günümüzde bir toplum, yaşadığı ortam hasebiyle bilim ve teknolojik araştırmaların hareketli ve gürültülü atmosferinden kısmen uzakta olsa da bunun oluşturduğu medeniyetin sonuçlarından günlük yaşam içerisinde hızla etkilenmektedir. $\mathrm{Bu}$ gelişmelerle, her ülkenin sınırı, diğer ülkelerin fikir ve ahlaki sistemlerine açık hale gelmektedir. Böylece bir ülkenin kendine has gelenek ve alışkanlıkları kolayca diğer ülkeye sızabilmektedir (Turan, 2005: 87-98) Bu sebeple Batı toplumuna mahsus laubalilik, ahlaksızlık, iyi ile kötüyü ayırt edebilme kabiliyetini kaybetme gibi özellikler Müslüman toplumlarda da görülebilmektedir. Haliyle bilim ve teknolojinin göz kamaştırıcı dış görünümüne aldanılmakta ve çağımızda yaşanan ahlaki çöküşler görmezden gelinebilmektedir. Medeni dünya ise, eğlence ve magazin olarak telkin edildiğinden akıllı düşünülememekte, olaylar ve nesneler tam anlamıla idrak edilememekte, yanlış yöntemler ile olumsuz yönler doğru görülmektedir (Musevi Lari, 2001: 29-31). İnsani düşüncelerin maddiyatla sınırlandırılması, insanlığın birçok fiziki ihtiyaçlarının yanı sıra, manevi ve ruhi ihtiyaçlarının olduğunu unutturmaktadır. Çağdaş dünyada dürüstlük gibi ahlaki kurallar salt maddi çıkar sağlamada kullanıldığından, ahlak da maddi çıkarların hizmetine girmektedir. Böylece iffet ve namusa değer verme gibi ahlak kontrolü ve ahlaksızlığı engelleyici yaptırımların olmamasının yanında bir yandan cinsellik tahrik edilirken öte yandan gayri meşru yollarla kolayca tatmin edilebilir ortamlar oluşturulmaktadır. Bu içgüdülerin etkisinde kalan erkek ve kadınların uygunsuz davranışlara karşı direniş güçleri azalarak iffet ve namus alay edilir hale gelmektedir (Musevi Lari, 2001:75-80). Ayrıca hastalık, yaşlılık, kimsesizlik, yalnızlık, suçluluk, yardıma muhtaçlık gibi yaşanan acı tecrübeler dolayısıyla sosyal hayatın karmaşıklığ 1 iç dünyanın karmaşıklığına ve mutsuzluğuna sebep olabilmektedir (Dündar, 2016: 284).

İşte yukarıda belirtilen bunca olumsuzluklar karşısında İslami eğitim sistemi, yaşamın tüm yönlerinde insana makul, doğal, tutarlı ve sağlam çözümler önermektedir. Bunun da fitratın gerektirdiği ilim, akıl ve bilgi çerçevesinde gerçekleşmesini istemektedir. Bu anlamda Yüce Allah, “Allah'ın kulları arasında O'ndan en çok korkanlar ancak bilginlerdir." (Fatır 3/28) buyururken, Hz. Muhammed de "İlim ve hikmet müminin yitiğidir. Her nerede bulursa onu alır." (Halebî, ts: 58-59), "Dünyayı isteyen ilme sarılsın, ahireti isteyen ilme sarılsın, hem dünyayı hem ahireti isteyen yine ilme sarılsı" (Halebî, ts: 22) demiştir. Böylece İslam'a göre sahip olunması istenen ilimler, sadece dini hükümleri içeren ilimler değil, her türlü tabiat ve insan bilimlerini de içine alan ilimlerdir (Bayraktar, 2017: 36) Dolayısıyla hayatın maddi ve manevi uyumunu 
öngören ve hedefleyen İslami anlayış, tutarlılık, olgunluk, kemal ve derinlik açısından insanlığa sunulan en mükemmel düzen ve emsalsiz bir nizamdır. Zira insanlık için gerekli olan saadet, hayır ve iyiliği içeren bu sistem, adeta şefkatli bir tabip gibi, insanoğlunun bütün dertlerine derman olan ve bütün acılarını dindirebilen bir yapıya sahiptir. İslam çağdaş anlayış ve düzenlerin düşmüş olduğu hataya düşmemektedir. Çünkü İslam eğitim sistemi, hiçbir gerçeği göz ardı etmeden insanla yakından uzaktan ilgisi olan bütün gerçeklere önem vererek, akıl ve mantığa uygun, tutarlı ve güvenilir bir yapıya sahip vb. bütün boyutlarda insanı yetiştirip eğitme ve onu kemale erdirme (Bayraktar, 1994: 15-18), iyi insan yetiştirme amacındadır (Kutub, 1975: 19). Bunu da doğum öncesinden başlatmaktadır. Nitekim Yüce Allah: "Rahimlerde sizi dilediği şekilde şekillendiren Allah'tır." (Ali İmran 3/6) âyetiyle insanlara henüz ana rahminde iken psikolojik ve fizyolojik özellikler kazandırdığını belirtmektedir (Bayraklı, 2015: 519-520). Yine Yüce Allah: "Birbirlerini istihdam etmeleri için, kimini ötekine derecelerle üstün kıldık." (Zuhruf 43/32) âyeti ile de dünya hayatının sürdürülebilirliği için zaruri olarak insanların tamamını bilge niteliğinde yaratmamış, belki farklı yetenek ve kabiliyetlerle farklı işbölümü ve mesleklerde olmalarını sağlamıştır. Aksi takdirde bir kimse diğerine boyun eğmez ve iş gördüremezdi. Bu da hayatı çekilmez hale getirirdi.

İslam dini insanın asıl yerini bilir, ona hak ettiği değeri vererek onunla tanıtır, sahip olduğu kimlik ve meziyetlerle başka varlıklara olan üstünlüğüne vurgu yapar. Nitekim bu hususla ilgili olarak Yüce Allah şöyle buyurmaktadır: "And olsun biz insanoğlunu şerefli kıldık. Onları karada ve denizde taşıdık. Kendilerini en güzel ve temiz şeylerden rızıklandırdık ve onları yarattıklarımızın birçoğundan üstün kıldık." (Isra 17/70), "İnsanı en güzel bir biçme yarattık." (Tin 95/4).

İslam dini, hayatın ölümle sona ermediğine, insanın ebedi bir hayatı olduğuna vurgu yapmaktadır. Böylece dünya ve ahiretin birbirinden bağımsız ve ayrı olmadıklarını belirtirken ruhla vücut arasında birlik ve ayrılmazlık olduğunu belirtmektedir. Bu sebepledir ki yüce bir kudretten alınan güç ve disiplin olan İslam dini, dünya ve ahiret yaşamı için programını belirtirken, amacının "ebedi insan yetiştirmek" olduğunu belirtmiştir. (Akseki,1957:5).

İslam dini, insan vücudunun, ruhunun ve aklının, her birinin kendine özgü, ihtiyaçları olduğunu belirlerken bu ihtiyaçları tam bir gerçeklikle ele almaktadır. Dolayısıyla fitri ve doğal dengeyi kurumaya çalışan İslam, dinin ahkâm, akaid, ahlak vb. bütün boyutlarında yaratılış nizamının değişmez prensipleri ile doğal dengenin bozulmamasını korumaya çalışmaktadır. Böylece insanın maddi ve manevi eğilimlerini birlikte ele alıp değerlendirerek onun huzur ve mutluluğunu sağlamaya çalışmaktadır. Zira İslam insanın fikri eğilimlerine değer verirken onun manevi boyutunda yücelmesinin yanında maddi boyutunda da ilerlemesini istemektedir. Bunun sağlıklı ve düzenli işlenmesi için kurallarını ve reçetesini ortaya koyan İslam, insanın kendi gayretleriyle ilerleyip tekâmüle ulaşabilmesi için ona düşünce hürriyeti tanımakta ve içtihat kapısını açık bırakmaktadır. Nitekim Yüce Allah : "Kötüye temayül ile iyiye temayül”(Şems 91/8) duygularını var ettiğini belirtirken, " Nefsi temizleyip parlatan gerçek kurtuluşa ermiştir.", “Onu kirletip gömen de ziyan etmiştir" (Şems 91/9-10), "Şüphesiz ona doğru yolu gösterdik, ister şükreder, ister nankörlük eder." (İnsan 76/3) âyetleriyle de kötüye ve iyiye yönelmenin kişinin cüzi iradesi ile gerçekleştiğini belirtmektedir. Dolayısıyla İslam, hayal dünyasının ürünü olan bir teori ve kuram değildir. Bilakis, bizzat anlamlı ve amaçlı bir hayatın varlık sebebidir, her şeyiyle tutarlı, hareketli ve yapıcı bir temele sahiptir.

Hayatla ilgili tutarlı ve kapsamlı bir düşünce biçimi olan İslam, ekonomik eksene dayalı Batı düşünce biçiminden çok daha ileri ve üstün bir anlayış şekline ve bakış açısına 
sahiptir. İslam, salt maddeci anlayışı reddeder; maddeyi, ekonomik çıkar ve hazzı, huzurun ve saadetin ölçüleri olarak görmez. Bu anlamda İslam eğitim sistemi, maddi çıkar ve hazzı önceleyen çağdaş Batı ve beşeri sistemlerden tamamıyla farklıdır. Çünkü İslam, insanı maddiyat ve ekonomik çerçevenin sınırlarına hapsetmez, onun maddiyatın yanında ulvi ve yüce alanları olan maneviyatını da ele alır. İslam'ın getirdiği düzen ile insanoğlu, yaratılışın genel ve özel gayesine uygun yüce ve ulvi hedeflere ulaşmak için büyük bir çaba gösterir hale gelir. Zira İslam'ın hedefi, ekonomik düzenlemelerle sinırlı değil, maneviyatı da içine alan kapsamlı ve tutarlıdır. Bunu anlayamayan ve Batı' nın etkisinde kalan Müslümanlar, çağdaş bilimin karşısında fikri ve bilimsel çağdaşlığ savunmalarının yerine, bu anlamda geri kalmışlıklarının sebebini sadece ekonomik etkenlere bağlamışlar ve ekonomik çağdaşçılığa yönelmişlerdir. Dolayısıyla İslam çağdaşçılığının, fikri ve bilimsel çağdaşçılığın yerine ekonomik çağdaşçılığa dönüşmesinin sonuçları, İslam ülkeleri için çok ağır olmuştur. Zira ekonomik çağdaşlık akımının, Batı'da doğurduğu olumsuz sonuçlar: -aile kurumunun değişmesi, kadınerkek ilişkileri, çevre kirliliği ve sömürü eğilimleri gibi-, geleneksel İslam eğitim kurumları tarafından hiçbir ayrım yapmadan fikri dâhil her türlü çağdaşçılığın karşısına çıkılmasına sebep olmuştur. Bu da, fikri donukluklara sebep olmuştur (Fazlur Rahman, 2016: 29-31).

Yüce Allah'a teslimiyet noktasında birey, İslami eğitim ile aynı zamanda kendi haddini ve sınırını öğrenerek, yaşanan olumsuzlukların ve ulaşılmayan hedeflerin ya kendi hataları ve gereken gayreti göstermemeleri sonucu, ya da bir hikmete binaen yüce kudretin iradesi ile oluştuğunu öğrenmektedir. Nitekim Yüce Allah şöyle buyurmaktadır: "Başınıza her ne musibet gelirse, kendi yaptıklarınız yüzündendir" (Şura 42/309), "Sizin hayır bildiklerinizde şer, şer bildiklerinizde hayır vardır. Allah bilir, siz bilemezsiniz." (Bakara 2/216).

Metodik olarak İslami eğitimde zorlama yoktur ve insanoğlu Allah'ın yoluna bilinçli ve güzel ifadelerle davet edilmektedir. Nitekim Yüce Allah ayeti kerimelerde şöyle buyurmuştur: "Dinde zorlama yoktur." (Bakara 2/256), "(Resulüm) sen, Rabbinin yoluna hikmet ve güzel öğütle çağır ve onlarla en güzel şekilde mücadele et! Rabbin, kendi yolundan sapanları en iyi bilendir ve O, hidayete erenleri çok iyi bilir." (Nahl 16/125), "O halde (Resulüm), ögüt ver. Çünkü sen ancak ögüt vericisin. Onların üzerine zorba değilsin.” (Gaşiye 88/21-22). Böylece İslami eğitim, insanın duygularını arıtıp temizler, insanı makul ve doğru bir mecraya yönlendirir. İnsanın mizacında olan unsurları fitri ve ulvi ihtiyaçları doğrultusunda uyum ve koordinasyon içerisinde harekete geçirir. Böylece aşrı eğilimler birçok vasita ve yollarla dizginlenip kontrol edilir, içgüdü ve eğilimlerin aklı mağlup etmelerine engel olunur. Haliyle insanoğlu yaşam sürecinde güç ve yeteneklerinin bir kısmını günlük geçimini temin etmede kullanırken, bir kısmını da manevi eğilim ve ruhi isteklerini karşılayabilme yolunda kullanabilmektedir. Bu durumda maddi ve manevi olarak disipline edilen bireyler, hem kendi içerisinde hem de toplumla bir düzen ve uyum içerisine girerek dengeli bir davranış ve gidişatla doğru ve dürüst bir hayatı sergilemektedirler (Dündar, 2011: 25).

İslami eğitim, Kur'an ve Sünnet merkezli yaratılışta var olan akıl ve mantığa dayalı olduğundan sağlam inanca, şüpheye bulaşmamış imana, ilmi kural ve ahlaki erdemlere dayalıdır. Ancak İslam, fitrata uygun bir yaşam biçimini sağlamak için bireyi birtakım esaslarla disiplinize ederken iradesi ile sorumlu tutmuş ve bunu da yapabildiği ile sınırlandırmıştır (Bakara 2/286). Toplumsal hukuk bağlamında ise, günümüz dünyasında ve Batı demokrasilerinde düzen sağlayıcılığın ve bağlayıcılığın temelinde, gerçekten yanlış bile olsa, çoğunluğun isteği bulunmaktadır. Yani insanın iradesi yanlış bile olsa meşru sayılmaktadır. İnsanın öğrenme kapasitesi ve bilgisi sınırlı olduğundan 
bütün çaba ve çalışmalara rağmen yaratılış özelliklerinin esrarengiz sırlarını keşfedememektedir. Nitekim Alexıs Carrel, bu konuda; "Başta bilim adamları, felsefeciler, düşünürler ve şairler olmak üzere insanoğlu kendisini tanıyabilmek için çok yoğun bir çaba göstermiş ise de bütün öğrendiklerinin, aslında insanın iç dünyasının sadece çok küçük bir bölümü olduğunu fark etmiştir." tespitinde bulunmuştur. Dolayısıyla bütün hayatını insanı araştırma ve incelemeye adayan bilim adamlarının, cevaplarını bulamadıkları sayısız sorular bulunmaktadır. Bu nedenle insanoğlunun sırrını bilmediklerinden olan kendisi için, her konuda yeterli olabilecek kanun ve kuralları ortaya koyabilmesi mümkün olmamaktadır. Bunun en bariz örneği ise, her gün artarak ortaya çıkan sorunlar ve olumsuzluklar karşısında bilim adamlarının ve hukukçuların çaresiz kalmaları ve kendi koydukları kural ve çıkardıkları kanunları sürekli değiştirip yenileme ihtiyacını duymalarıdır. Dahası; beşeri kanunları düzenleyip tasvib eden insanlar, nefsi arzularını, şahsi eğilimlerini, bencillik, çıkarcılık, makam hırs1, özel düşünce biçimi ve olaylara bakış tarzı gibi birçok şartlardan bilerek veya bilmeyerek etkilenmekte, kendi düşünce, eğilim ve bakış açılarına uygun kanunlar çıkarmaktadırlar ve bu doğrultuda hareket etmektedirler. Nitekim Aristo, kanun koyarken bazen Eflatun'a karşı beslediği kıskançlık ve hased duygularını tatmin etme yoluna gitmiş ve kimi zaman da İskender'e olan sevgisini göstermek istemiştir. Eflatun ise, Atinalıların zulüm ve zorbalıklarından duyduğu rahatsızlıkları ve nefreti düzenlediği kanunlara yansıtmıştır. İşte beşeri sistemlerin kanunları beşeri olduğu ve ilahi hükümlere göre tanzim edilmediği için bir şekilde güç ve iktidar sahiplerinin eğilim ve çıkarları doğrultusunda şekillenmektedir. Oysaki İslam'da, tek temel ve yaptırıcı güç, Yüce Allah'ın iradesi olduğundan burada kanun koyucu tek merci, ulûhiyet ve yaratıcılık makamıdır. Böylece insan varlığının bütün sırlarını bilen ve bireylerin farklı fiziki ve ruhi özelliklerine göre aralarındaki ilişkileri sağlıklı bir şekilde düzenleyen Yüce Allah'ın dini olan İslam, bireysel ve toplumsal hayatın bütün boyutlarında hakkı uygulamayı amaç edinmiştir. Nitekim Jan Jack Rousseou: "En mükemmel kanunu çıkarabilmek için mükemmel akla sahip bir bilge lazım; insanoğlundaki bütün şehvetleri bilen, ama bunları bizzat hissetmeyen, tabiatla ilgisi olmayan fakat tabiatı çok iyi tanıyan, mutluluğu insana bağlı olmayan, ancak insanın mutluluğuna yardımcı olan bir deha gerekir." sözleriyle bu konuda ihtiyaç duyulan aklı/varlığı veya otoriteyi dile getirmiştir. Tabi ki bu vasıflara uygun tek varlık, insanı ve tabiatı yaratan ve tüm sırlarını bilen, hiçbir şekilde insana ihtiyacı olmayan ve her şeyden münezzeh olan Yüce Allahtır (Musevi Lari, 2001: 167-172).

Her halükarda fitrata ve fitratın gereğine önem vererek insanın maddi ve manevi ihtiyaçlarını dikkate alan ve karşılayan, dünya ve ahiret saadetini temin eden İslam; aynı zamanda ilme ve bilime önem vermiştir. Batılıların da Müslümanların ilminden istifade ettiğini ve bu ilmin İslam dünyasının modern dünyaya en büyük hediyesi olduğunu İngiliz tıp bilgini ve antropologu Robert St. Briffault, The Making of Humanity adl kitabında dile getirmiştir. Böylece İslam dünyasının yanında Batı'yı da aydınlatan İslam medeniyetini, doğruluk ve adaletin timsali olarak gören bazı Avrupalılar, İslam'1 Avrupa'nın geleceği için temenni etmişlerdir. Nitekim ünlü Alman şairi ve düşünürü Goethe: "Er-geç geleceğimizde İslam yatar." ifadesini kullanmıştır. Aynı zamanda Fransız Kralı I. Napolyon, 1798 yılında Mısır'a askeri çıkarma yaparken Mısır'da gördüklerinden etkilendiğinden ülkesine döndükten sonra : "Bütün ülkelerin eğitimli ve hikmetli insanlarını bir araya getirerek tek hakikat ve insanları mutluluğa götürebilecek tek kaynak olan Kur'an'ın ilkeleri üzerine bir idare şeklini kuracağım zamanın uzun olmayacağını ümit ediyorum" ifadesinde bulunmuştur (Bayraktar,2017: 66-67). Ancak İslam'ın ortaya koyduğu din ve inanç hürriyetine ve insana sağladığı dünya ve ahiret saadetine yönelik, tarihsel süreç içerisinde, birçok olumlu örnekleri olduğu gibi bazen 
İslam'ın ilkelerinin yanlış anlaşılması ve yorumlanması, bazen de bu ilkelere uymada yapılan kusur ve ihmaller, birtakım yanlışlıklara sebep olabilmiştir (Ünal v.dğr., 2015: 20-21).

\section{SONUÇ}

Modern çağımızın insanı, yaşadığı dünyada birçok sorunla karşılaşmaktadır. Bunlar, hastalık, sakatlanma ve ölüm gibi sorunlar olabildiği gibi, bu çağın getirdiği imkânlardan kaynaklanan sorunlar da olabilmektedir. Zira çağın teknolojik imkânlarıyla globalleşen dünyamızda oluşan gelişmelerden haberdar olunmakta, ihtiyaç duyulan ve ulaşılamayan imkânlarla ilgili sorunlar yaşanmaktadır, yapılan savaşlarda binlerce kişi ölmekte veya sakat kalmaktadır. Bu imkânlarla sadece maddi refah dikkate alındığında manevi ihtiyaçların temini eksik kalmakta ve insanlar huzursuz olmaktadır. Salt maddiyatı hedef edinen, bilim ve teknolojide ileri bir seviyeye ulaşan Batı, eğitim anlayışında insanın manevi boyutunu ihmal ettiğinden adeta gençliğin yozlaşmasına zemin hazırlamaktadır. Çünkü burada tüm değerler maddiyatla değerlendirildiğinden nefsi arzular ile şehevi duygular kontrolsüz işlenmektedir. İçki, kumar gibi olumsuzluklar yaygınlık kazanmaktadır. Kilise bile dinin manevi boyutunu bir kenara bırakarak burada dans oyunları oynanmaktadır. Dolayısıyla bu çağda yaşanan sorunlara bu anlamda çözüm oluşturamayan Batı eğitimine gore İslami eğitim, yaşanan bunca olumsuzluklara çözümler getirebilmektedir. Zira İslam'a göre, insanın hem maddi ve hem de manevi ihtiyaçlarını karşılamak üzere eğitim yapılmaktadır. Böylece maddi ve manevi ihtiyaçlarına el atan ve bu anlamda çözümler üreten İslami eğitim ile çağımızın insanı söz konusu sorunlarına çözüm bularak mutlu ve huzurlu olabilmektedir.

\section{KAYNAKÇA}

Akseki, Ahmet Hamdi. Íslam Dini, İtikat, İbadet, Ahlak. Ankara: Nur Yayınları, 1957.

Attas, S.M.N. "Preliminary Thoughts on the Nature of Knowledge and the Definition and Aims of Education". Aims and Objectives of Islamic Education. Ed. Syed Muhammed al-Naquib al-Attas, Hodder and Stoughton. 19-47. Jeddah: King Abd al-Aziz University, 1979.

Başar, Erdoğan. "Türkiye'deki Eğitimin Tarihsel Gelişimi”. Eğitim Bilimine Giriş. Ed..Özcan Demirel-Zeki Kaya.23-66. Ankara: Pegem Yayınları, 2010.

Bayraklı, Bayraktar. "İslam Eğitimi ile Batı Eğitim Sistemleri Arasındaki Temel Farklar". Marmara Üniversitesi Ilahiyat Fakültesi Dergisi 7-8-9-10 (1995): 519-528.

Bayraklı, Bayraktar. İslam ve Eğitim. İstanbul: Düşün Yayıncılık, 2015.

Bayraktar, M. Faruk. Íslam Ĕgitiminde Ö̆rretmen-Öğrenci Münasebetleri. İstanbul: İFAV Yayınları, 1994.

Bayraktar, Mehmet. Íslam'da Bilim ve Teknoloji Tarihi. Ankara: TDVY, 2017.

Dündar, Mahmut. İlk Dönem İslami Eğitim-Öğretim Faaliyetleri. İstanbul: İşrak Yayınları, 2011.

Dündar, Mahmut. "Religious Counselingand Guidance in Social Environment". Looking Behindand Before. Ed.William H. Taylor. 284-294. London: AGP, 2016, 
Halebî, İbrahim b. Muhammed. et-Tac I, Misır,ts.

Ertürk, Selahattin. Eğitimde Program Geliştirme. Ankara: Yelkentepe Yayınları, 1984.

Fazlur Rahman. Íslam ve Çağdaşlık. çev. Alparslan Açıkgenç-M.Hayri Kırbaşoğlu. Ankara: Ankara Okulu Yayınları, 2016.

Gramer, J.F.ve Browne G.S. Çăgdaş Ĕ̆itim (Milli Ĕgitim Sistemleri Üzerinde Mukayeseli Bir Inceleme). çev. A. Ferhat Oğuzkan. MEB Devlet Kitapları. İstanbul: Milli Eğitim Basımevi, 1974.

Halstead, J. Mark. "İslam Eğitim Anlayışı". çev. Semra Çinemre. Ondukuz Mayıs Üniversitesi İlahiyat Fakültesi Dergisi 32 (2012): 273-291.

Hesapçığlu, Muhsin. Türkiye'de Cumhuriyet Döneminde Eğitim Politikası ve Felsefesi. M. Ü. Ĕ̈itim Fakültesi Ĕ̆itim Bilimleri Dergisi 29 (2009): 121-138.

Husain, S.S.\& Ashraf, S.A. Crisis in Müslim Education. Jeddah: Hodder \& Stoughton, 1979.

İmamoğlu,İ.H.“İslam'ın Kadim Geleneğinden Medreselerden Vatandaşlık Bilincine Mekteplere: Hedef-Içerik ve Paradigma Sorrgulamaları", Muş Alparslan Üniversitesi Medrese Geleneği ve Modernleşme Sürecinde Medreseler Uluslararast Sempozyumu ( 05-07 Ekim 2012). Ed.Fikret Gedikli. 1:185-198. Muş: M.Ş.Ü. Yayınları, 2013.

İnalc1k, H. “Atatürk ve Türkiye'nin Modernleşmesi”. Ankara Üniversitesi'nin 60. Kuruluş Yılı Armăganı Atatürk ve Türk Dili ve Edebiyatı,Türk Eğitimi ve Türk Kültürü Konusunda Seçme Yazılar. Ed. Doğan Atılgan : 289-296. Ankara: Ankara Üniversitesi Yayınları, 2006.

Keklik, Nihat. Allah-Kâinat ve İnsan. İstanbul: İstanbul Üniversitesi Edebiyat Fakültesi Yayınları, 1967.

Köylü, Mustafa. “İslam Eğitiminin Temel Özellikleeri”. Ana Hatlarıyla İslam Ĕgitim Tarihi. ed. Müstafa Köylü-Şakir Gözütok:31-72. İstanbul: Ensar Yayınları, 2017.

Kutub, Muhammed. İslam Terbiye Metodu ve Ahlak Sistemi. çev. Ali Özek. İstanbul: Hisar Yayınları, 1975.

Louise Cripps Samoiloff. Meöories and Commenttaries. American: Associated University Presses, 1997.

Mengüşoğlu,Takiyettin. Felsefi Antropoloji.İstanbul: İstanbul Üniversitesi Yayınları, 1971.

Muhammed Esed. Yolların Ayrılış Noktasında İslam. çev. Hayreddin Karaman. İstanbul: İz Yayıncılık, 2017.

Musevi Lari, Seyyid Muçteba. İslam ve Batı Medeniyeti. çev. İsmail Bendiderya. Kum: Muessese Çap el-Hadi, 2001.

Turan, Sevgi. "Öğrenen Toplumlara Doğru Avrupa Birliği Eğitim Politikalarında Yaşam Boyu Öğrenme”. Ankara Avrupa Çalışmaları Dergisi 5/1 (2005): 8798.

Russell, Bertrand. Mistisizm ve Mantık. çev. Ayseli Uluata. İstanbul: Varlık Yayınları, 1972. 
Ünal, İsmail Hakk1, v.dğr. İslâm Kültüründe Höşgörü (Bir Arada Yaşama Tecrübemizin Esasları-Örnekleri). Ankara: DİB Yayınları, 2015.

Wan Daud W.M.N. The Educatıonal Phlosophy And Practıce of Syed Muhammed Naquib al-Attas: An Exposition of the Original Concept of Islamizatıon. Kuala Lumpur: International Institue of Islamic Thought and Civilization, 1998. 